総説

\title{
英国における食肉研究事情
}

\author{
鈴 木 敦 士*
}

\section{Review of Current Research in Meat Science in United Kingdom}

\author{
Atsushi Suzuki* \\ * Laboratory of Biochemistry and Technology of Animal Products, Faculty of \\ Agriculture, University of Niigata, Igarashi nino-cho, Niigata, 950-21
}

著者は, 1982 年 10 月より, 1983 年 6 月までの 9 か月 間, 文部省在外研究員として, 英国の食肉研究所 (Meat Research Institute, 以下 MRI) で研究する機会を得た ので，その間の印象や経験をむとに，この研究所の組䄉 や研究動问を紹介したい。それによって，英国に扣ける 食肉研究の現況を伝えることができれば幸いである。

\section{MRI の所在地及び組織と活動}

MRI は, ロンドンの西 $200 \mathrm{~km}$, 英国西南部のプリス トル市の郊外, ラングフォードといら町にあり, ブリス トル大学 獣医科大学のキャンパスの一画に位置してい る。1922 年にケンブリッジに設立された低温研究所か ら, 1967 年に, 食品研究所 (Food Research Institute, ノリッジ市にある）とともに分離独立したものである。 研究所の外観を図1に示す。

MRI は, Agricultural Research Council (ARC) 直 辖の研究所の一つであり, A. J. Bailey 所長以下, 約 100 名の研究員を含む, 約 200 名の職員と次に示す 6 つの部 門から棈成されている。

Animal Physiology Division

Engineering and Development Division

Food Quality Division

Muscle Biology Division

Analytical Chemistry Division

Administration Division

MRI の施設には, 各実験室の他に, 正規の屠場, 解 体室, 貯蔵用恒温室, 肉を冷却, 凍結, 解凍及び加工す

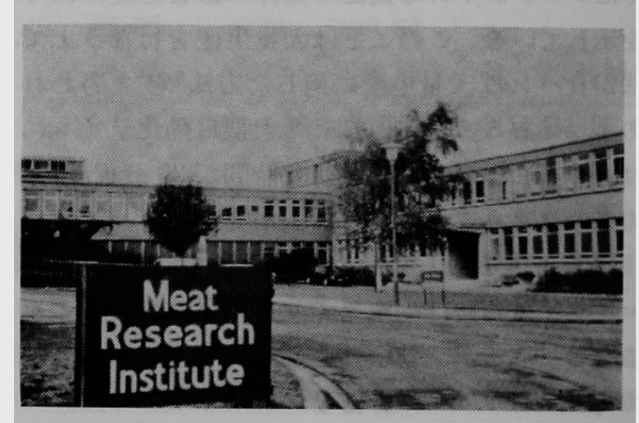

Fig. 1 Meat Research Institute

るだめのパイロットプラント, 調理室, 官能検査室など があ。

MRI はその設立以来, 食肉に関する基礎から応用に 至る研究により，肉の科学や加工技術の発展に貢献 L.て いる。英国がヨーロッパ経済共同体 (EEC) に加盟して からは, ヨーロッハの食肉研究所との共同研究も活発に 行なわれるよらになった。又, プリストル大学獣医科大 学との協力により, Meat Science コースの修士課程学 生の教育む行なえるようになっている。

\section{2. 研究動向}

MRI の研究は, 以下に示す $6 つ$ 以プロジェクトか ら成り立っている。

1）品質の高い食肉の効率的な生産と，屠殺過程での 肉質の維持に関する研究。

2）生体や枝肉の組成を推定する方法の開発, ならび

\footnotetext{
* 新潟大学農学部音産製造学教室（干 950-21 新潟市五十嵐二ノ町 8050)
} 
に新しい屠殺法や包装法を利用し，肉音からできる だ高収萃，高品質の肉を得る万法の開発。

3）屠場での枝肉処理中の街生管理及び流通過程での 食中清と食肉腐敗の防止に関する研究。

4) 食肉生産に打ける冷却, 凍絬及び解凍といった unit operation のための基礎的データの集積, なら びにその工業的規模への庆用に関する研究。

5）食肉の塩せき（curing）上品質及び安全性につい ての研究。

6)食肉の特性（テクスチャ一，保水性，風味，色） を正しく評価する方法の開発，ならびに特性に影響 を与える各種要因に関す万研究。

\section{3. 研究内容}

前述の大プロジェクトのもとに行なかれている主な研 究についての概要を項目ごとに紹介する。

1）屠殺前の肉畜の取り扱いと肉質の問題

屠殺前の肉畜の取り扱いが肉質にどのよらな影響を与 えるかという観点から，Dark cutting beef 又は pork, PSE (pale, soft, exudative) pork, ならびに丰の blood splashの3つが取りあげられている。

Dark cutting は, 死後の極限 $\mathrm{pH}$ が下がらない場合 （pH 6.0 以上にととまる）に生じ，保水性が高いため に，酸素の筇肉内部への抎散が遮く，酸化ミ才グロビン の形成が悪いために肉色が暗赤色となったものである。

屠殺前の㳙肉中のグリコーダンの量や，筇肉や肝缄中の 脂肪の量が影䜾する。屠殺前に肉畜に与えられるストレ スの結果, グリコーゲンが消費された場合, 又, 脂肪分 解を抑制するカテュールフミンの分泌か增加した場合に dark cutting が起こりやすくなる。脂筫の分解を促進寸 る薬品（特にカフェイン）を注射すると, dark cutting meat の出現を阻止することができるい゙。

PSE 肉は，屠殺後の屠体の温度が高い間に，笳肉の $\mathrm{pH}$ が異常に速く低下した場合に起こる。ミトコンドリ アや觔小胞体の $\mathrm{Ca}^{2+}$ 調節能力が低下し，筋原線稚中に 遊離 $\mathrm{Ca}^{2+}$ が增之，急激な死後硬直を起こすためと考古 られる。主に平滑能に作用するオキシトシンの上らな脸 下瑟体ホルモンを与方ると，篎肉の $\mathrm{pH}$ 低下速度を遈く するので,PSE 㕄の発现が阻止されるといら結果を得て W范。

Blood Splash は，羊の肉に見られる血液斑点のことで ある゙。屠殺法の効果・効率上羊肉中の血液斑点の出現 との関俰について研究を進めている。植物性のクマリン (出血死を起こす) の摄取, 温度, 湿度, 屠場での運動, ストレス, 輸送法, 家畜小屋の構造, との関係を研究し
ているが、これといった結論は得られていない。

2）成長效率と枝肉組成のホルモンによる制御

雄牛上崔牛を使い，去勢又は性ホルモン処理した時 の, 成長效孛, 生体の物理的及び化学的組成, 肘壳可能 な肉の歩留り，血獎ホルモン濃度への影慜，についての 基礎的なデー夕を得るために，去等雄牛と去勢しない堆 牛, 卵巣叟除雌牛と术処理雌牛，去晸十性ホルモン処理 雄牛と末処理婎牛，の組子合わせにより研究を進めた。 末処理の雄牛の方か，去勢牛や雌牛に比べて，赤肉の 割合が高く，エストロシェンやアントロジェンといら同 化ホルモンの效果が諗如れた，しかし，その生理的機 構については不明な点が多い1。

更に，雌牛の赤肉(繁殖中泌乳には必要ないと考学ら れている）の生産効率を改善する方法，又，代謝，枝肉 組成及び肉質を支配する神経内分泌要因についての研究 も進められている。

赤肉の多い: Pietrain 豚は, 体脂肪が動き易く, これ が赤肉の発達につながっている。Pietrain 康は，脂肪の 多い Large White 豚に比べてインシュリンの分泌が少 なく，この差が脂肪沈着の速さの差となるらしい"5。

慗性滈熱㱏腇の血流と，肝喴や筋肉中の基質の利用に ついての研究も進められている。悪性高熱症侯群では, 遊離脂肪酸の利用が低下し，これが dark cutting 迠の 原因ではないかと考えられている。又，エネルギー源の 供給とい5見地から，組織への血夜供給の重要性も指摘

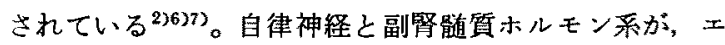
ネルギー源の代謝と沈着を支配する点で，又，血管の活 動を制御する点で重要である。これらの研究が，原，牛， 羊のストレスへの反応との関係で, 又, 屠場での動物の 取り扱い方や，屠殺方法の効率との関係で重要になって きている。

3）冷却之眝藏に関する問題

枝肉及びカット肉の冷却, 凍結, 解凍に和ける熱の移 動㙨構について研究し，食肉工業界の要望に対処しよ5 としている。

(i) 冷却

仔牛の枝肉の冾却速度に関する研究が, Cold shortening (冷短樎) ${ }^{* 1}$ と結びつけて進められ, 冷却開始後, 最初の 10 時間は, 冷却室の温度を $8^{\circ} \mathrm{C}$ 以上に維持するな らば，枝肉のどの部位にも toughening*2 は生しないこ とが判っだっ。電気刺激を行なった場合の冷却速度につ いてす研究を進めている。

(ii) 倲結

骨を除去した肉塊を商業規模で凍結するのに好適な条 


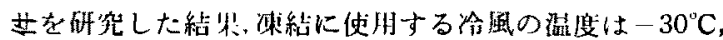
風速は $5 \mathrm{~m} /$ 秒がよいことが判った。この場合，15 cm の

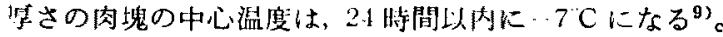

(iii) 解碀

相㞔していない肉の鬼を，空気中及び真空下で解凍す るための研究を行なった。 $15 \mathrm{~cm}$ の厚さの肉塊を，24時 間かけて解凍寸る場合， $10^{\circ} \mathrm{C}$ あるいは，それより高い温 度の真空下での解凍が良い，又，空気解凍の場合，秒速 $3 \mathrm{~m}$ 以上の，20Cの温蛙あてるのが良いことが判っ た。 $15 \mathrm{~cm}$ の厚さの肉塊をカートンボックスにいれて封 をした場合，48時閒で解凍するためには，秒速 $3 \mathrm{~m}$ 以 上，20ㄷ の温風を常に供給することが必要である10)。

4) 肉の組成の物理的測定法

動物を殺さずに，その枝肉組成を子予测するための物理 的な方法の開発が行なわれている。超音波を利用した脂 肪の厚さの湘定方法には2通りある。超音波パルスの反 射を利用して測定した生体の脂肪の厚さは，枝肉の切断 面から推定した值と同程度の精度があることを明らかに

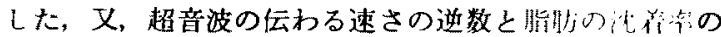
間に相刚のあることが判っだ。 肉之脂肪組秚の混合物中の脂肪量の推起に利用し上5上 いら研究も進められている。

熱の移動と，肉質や組成を結びつけた，肉の物理的性 質についての研究が行なわれている。超音波の伝わる速 さは，肉が凍結されると劇的に增加するので，速度を測 ることにより，凍結された肉中の水の量が判る。又，熱 変性, 凍結及び解涷処理した肉の核磁気共鳴 (NMR) を 湘定し，肉中の水の状態を知るための基礎的データを得

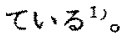

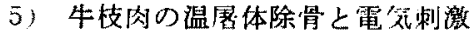

電気刺敫 (Electrical Stimulation, 以下 ES) を行な った場合と行なわない場合の，温屠休除骨（Hot Deboning，以下 HDB）の適用性について，害用化規模で㰠

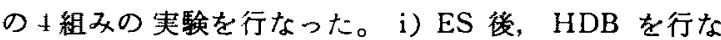
って淔ちに冷却，ii）ES 後，24時間急速に冷却してか 5冷屠体除骨 (Cold Deboning, 以下 CDB), iii) HDB 後, 象っくり冷却, iv) 慣例通りの 48 時間冷却後, $\mathrm{CDB}$ 。

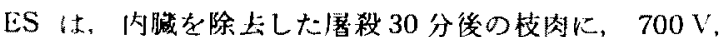
25ハルスの電生を22 秒かけることにより実施した。ひ の結果を以下に記す。i) HDB 肉の $\mathrm{pH}$ は, 包装㭙（死 後 2 時間目）, ES 処理すると0.3 低かったが，眝荿の 最終時（1CC，7日目）には，差が認められなかった。 ii) ES 処理した枝肉からの肉は, 死後 10 日目で柔らか

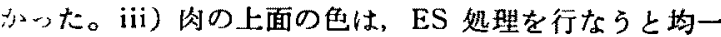

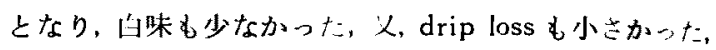

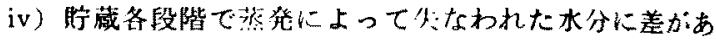
ったけれどし，真架包装した肉では，HDBとCDBと の間に美がなかった。しかし，一週間眝藏後，小売用に カットした場合, HDB 肉はトリミングが少なくてすみ、 小売肉の步留りは高かった。v) HDBの場合, 冷却コス トが節減でき，全体の処理速度を上げることが可能であ る。vi）鿉生物学的には, $\mathrm{HDB}$ 肉は, 包装の時点で, $\mathrm{CDB}$ 肉よりも細菌の数が多かのた。このことは，館藏 中, 細菌の成育が $\mathrm{CDB}$ 肉よりも高いことを示してい る。これを防くた斿には，HDB 肉は，すみやかに，か つ效率よく泠却されることが望ましい11)。

枝肉を急速冷却する場合, Cold shortening をさける ために，ES を導入する必要がある。ES 処理は，ATP の分解や糖代韵を促進し，正常な死後硬直の開始時間を 短縮することができる。このことは，貯蔵中に肉の柔ら かさを改善する自然の熟成過程の促進につながり，通常 の2週間の紫吊で得るオかさと同じものを、2〜3日て 達成できる゙。

MRI の開発による, skin packing machineによる包 装法は，HDB 灲を，あたたかいうちに真空包装して令 却する万法であり，凍結しても色調を損ならことのない のが特徽である゙”。

また，屠場における作業上の安全性の点から，高電王 の ES に代わる，低電圧によるESについても研究が進 められている。

6）食肉の微生物に関する問題

畜肉の污染源や細菌による生産物の研究が行なか报て る。食中証を起こした肉及び肉製品から分跬した細菌の うちの 86\%がェンテロトキシン生産性であった。Clost ridium perfringens は, 他の Clostridium 属のものに比 へて，低濃度の酸素に耐性があり，酸化還元電位を， Cl. botulinum かi成育し，赫の生産を可能にするまて 低下させることができた ${ }^{12)}$ 。Cl. botulinumについては，

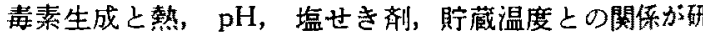
究され，又，その成育を確認する方法の開発が進められ ている。

生肉，具空包裝肉及び塩せき肉を治葴中に，漖生物心 成肎に伴なって变化する化合物についてての研究から，次 い和果を得た ${ }^{13)}$ 。i） $5 \mathrm{C}$ で眝蔵した正常の $\mathrm{pH}$ を示子肉 の head space 中に, 硫化水素 $\left(\mathrm{H}_{2} \mathrm{~S}\right), \wedge$ イルハルカフ タン (MM), シャチルサルファイド(DMS), ジチル シサルファイド(DMDS) の 4 つの揮発性含硫化合物の 们在を認めた。又，真空包装肉中の MM とDMDSは 
渴内細菌の存在と関保し， $\mathrm{H}_{2} \mathrm{~S}$ と DMS が腸内細菌な らびに乳酸菌の存在と関係することが判った。ii）真空 包装した正常及び高い pH の牛肉では，Brochothrix thermosphacta Perratia liquefaciensによって, 滅菌 肉中では，肉の中に存在する䤃素に上って，酢酸が作ら れることが判った。iii) B. thermosphactaによって作ら れる庯敗化合物として，ダルコースからの酢酸，コ七卜 イン 2,3-ブタンディオール，バリンからのイソ酪酸， ロインンからのインパリリン酸が確認されている。

その他，熟，冷却，乾燥，放射線照射なとにより，細 菌が受ける影響についての研究か，大晹菌やサルモネラ 菌を使って進められている。

7）肉の食味特性に影暨する要因

(i) 熟成期間

生肉を凍結する前にどの程度熟成させるかということ か，肉の硬さに影整する。食肉会社の標準では，牛肉の 場合，2〜6 日間の熟成を行ならが，ロイン部が影繁を受 け易く，機器による測定で，測定総数の $30 \%$ が硬い上い う結果を得た。就成期間を 14 日に延ばすと，硬いるの は5\%に减り，28 日後にはゼ口になったり。

(ii) ホルモン投与

$300 \mathrm{mg}$ のフンドロジェン (trebolone acetate) と 45 mg のエストロジン (hexoesterol) を屠殺前の90日間 投与した去浆雄牛の口イン部の肉について研究した結 果, 無投与区に比ぺて, 風味や多汁性には差か認められ なかっだ。

\section{(iii) 飼料蛋白質}

菜敇が、EC 諸国での油糧種子琼物としての主要な地 位を占めるよ5になったため，蛋白質に富も油粕の飼料 としての利用を考える必要が生した。莱種粕を給与した 豚と，大豆粕を給与した豚の，肉色，風味、テクスチ十 一のいずれにも有意差は認められず，ローストした場合 に，いずれも良い食味性を示しだ。

\section{(iv) 脂肪量}

大変赤肉の多い豚肉と，やや赤肉の多い豚肉の間の， 香らかさと風味には差がなかったけれども，赤肉の大変 多い肉は，多计性にそしいと判定された ${ }^{14) 。 ~}$

\section{(v) 品種}

Texel, Dorset Down, Suffolk, Oxford, Cotswold 及 び Southdownの6種の羊肉の食咮特性を比較した結 果, 色、テクスチャ一，風味，多汁性に品種間の差は認 められなかった1)。

8）施肉及び食肉の楼造と生理学に関する問題

食肉組織との関保から，収樎禹白質の相互作用の機構

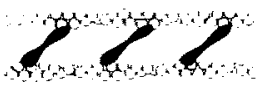

(a)

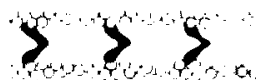

(b)
Fig. 2 Cross-linking of actin filaments by heavy meromyosin

The cross-links usually take the form of diagonal rungs implying an antiparallel ar. rangement of filaments (a), but occasionally $\mathrm{V}$-shaped links indicative of parallel filaments are also seen (b).

及び相互作用に影㹕する要因を明らかにしようと試み た。

(i) ミオンン及びへビーィロミオンンと細い線程と の相互作用

ミオシン分子は 2 つの球状の頭部を持ち，そのおのお のはフクチンと結合できる。一般にミオンンの 2 つの頭 部は，同じ細い、線雓上にある隣接したアクチンと結合す ると信じられている。しかし，MRIでは，闹しミオシン 分子の 2 つの頭が，異なる細い線維上のアクチン分子と 結合するとい5, “two-filament interaction”説を提唱 した。電子湿微鏡による観察から、へビーィロミオンン が，図2に示すよらなアクチンとの架橋を作ることが判 つた。この試験管内での two-filament interaction は, 生体内で起る可能性もある。つクチンとミオシンを混ぜ た時の 粘度の 劇的な增加は，少なくともその一部は， two-filament interaction のためではないだろらか

（ii）太い線維の脱重合

太い線維は，主にミオンンからできているが，その詳 細な椣造は完全に解明されているわけではなく、いくつ かの末知の成分を含んでいる。塩を加える之，分離して おいた場合です，あるいは箭原線維のままです，太い線 稚は脱重合を起こす。この分解過程は，ミオンンと他の 構成成分との結合関保を反映し，新しい構成成分を見出 そらとする研究を促進する。脱重合は，太い線維の両端 から中央の H-zone 淌って進む。両端が除去された 後，C-蛋白質“3 が結合していた領域はほどけ，更に塩滣 度が增すと，残りの線維が脱重合を起して H-zone に “Stub”と呼ぶものが集まる。丁度よいイオン强度を選 ぶと，両端の無い線䧽と“Stub”，の中間にあたる，安定 で部分的に解重合した中間体を作ることができる。この 標品のイオン強度を下げると，解重合した成分の再配列 が可能になり，この合成ミオンン線維の成長の機構は, 生体内での太い線稚の形成機漛の研究に手がかりを与え 
$3^{16)}$ 。

(iii) 死後硬直の発現と肉の硬さ

哺乳動物の等線維は，好気的条件下では，死後硬直の 開始が遮くなる, 又, 硬直開始時間の温度依存性をみる と, $10 \sim 15^{\circ} \mathrm{C}$ で一番漣く, $2{ }^{\mathrm{C}}$ では一番早い。 $2^{\circ} \mathrm{C}$ で異 常に早く硬遖に入るがここれは Cold shortening のため である。硬直による硬さの增加と，ATP 濃度の減少は数 時間にわたって持続する。一方，単一線維の場合は，硬 直開始から聚大硬直に達するまでの時間は短かく $\left(20^{\circ} \mathrm{C}\right.$ で約 10 分), ATP 濃度の減少も速い。多くの線維から 成る線維束で，最大硬直に達するまでの㭙間がかかるの は，線維束を構成するおのおのの線維に和计る ATP 再 生力に差があり, ATPの保持能力む異なる結果である1)。

細胞膜を除去した哺乳動物の適当な大きさの筋肉は, ATP が欠之すると急速に硬直する。この筋肉を適当な 溶夜に浸すと，強い硬直を保つことができる。しかし $\mathrm{Ca}^{2+}$ 瀁度が $0.5 \mathrm{mM}$ 以上になると, 硬さが急速に失な われる。 $\mathrm{Sr}^{2+}$ にも同し効果があるが $\mathrm{Mg}^{2+}$ にはない。硬 さの低下は， $\mathrm{Ca}^{2+}$ の溓度を下げても元に戻らない，又， この見象の $\mathrm{pH}$ 依存性とインヒビターについての研究か ら、この硬直の低下は，七リンプロテフーゼのCa-活性 化酵素 (CAF) 又は，カテフンン系の醅素の作用のため とは考えにくい。この現象は，等線維を值接測定器に一 ないた時には認められず，腱を介してつないだ時には認 められたので，筋線維上腱を結びつ汁る物質の分解によ るのではないかと考えられる1。

9）筇原線維蛋白質及び結合組織の構造の破壊と蛋白 分解酵素

熟成中の筋原線䧽蛋白質の変化を SDS-ポリアクリル フミドダル電気泳動により分析した結果, $\mathrm{pH} 6.0$ 以上 で起こる変化は CAF の作用によると考えられる”。 の醇素は Z带を破壊する能力を持っている。よく洗った 線維を使っての自己消化実験では， $0.1 \mathrm{mM} の \mathrm{Ca}^{2+}$ が あ九ば，デスミンが破壊され，Z带は可溶化した。これ は, $\mathrm{CAF}$ のうちの, 低 $\mathrm{Ca}^{2+}$ 要求型の作用に上るもので あ万う。高 $\mathrm{Ca}^{2+}$ 要求型と低 $\mathrm{Ca}^{2+}$ 要求型の 2 種の $\mathrm{CAF}$ の局在に関する研究む行なわれている。

コラーゲン分解能を持つ醭として，カテフシンBと Nがいろいるな動物のいろいるな䁍器から分離精製され ている, 又、カテンシン $\mathrm{L}$ もラーゲン分解能を持つと 報告されている。MRIでは，特にカテブシンBとNkつ いての研究を行なっている。カテブンン B， N，L は， 未変性コラーゲンの, ヘリックス構造を持たない末端の ベプチド域を切る。コラーゲンの分子内架橋は，この末
端ベフチトに由来するのて，前述のカテンンンは，線維 状コラーダンを效果的に切断することができる。カテフ シンBとLは，コラーゲン以外の蛋白質やベブチドを基 筧として利用できるが，カテフンンNについては、コラ 一ゲン以外の適当な基質が見つかっていない、17)。

また、コラーゲンスポンジを皮下に移植し，細胞中に 唚入させ，組織培着を行なって，移植されだラーダン の分解嘰構を研究した。ある種の醉菜インヒビターや抗 炎症剂が，この分解を抑制することから，中性ブロテフ

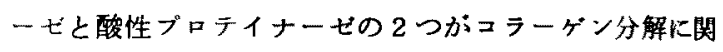
与しているものと考えられる ${ }^{18 \%}$

10）結合組織に関する問题

筋肉内の結合組織の明確化及びその变化について研究 した。 5 種類のコラーゲンの5ち，4つの筋内内で分 布を明らかにした。即ち，タイプIは，能外膜と筋周膜 に, タイプIIIは等周膜に, タイプ IV と V は蛒線維内 䩗に分布することが判った。肉組織中でのコラーゲンの 多形性の役割を研究するため, 胼肉と他の組織中に存在 するコラーダンの相対的量を比較した結果, タイブ III コラーゲンが便い肉の中に認められた。タイフ III コラ ータンは, S-S 結合やリジン誘導体の架橋に上って安定 化され，肉の硬さに大きな役割を果すのかもしれない、19 20)。

笳肉内コラーダンの架橋の度合と型が肉組繊にとって 重要なことは確立されている。シッフ塩基の架桥の化学 は上く研究されているが，それは成熟した組織に見出 される安定な非還元性の架橋形成への中間体にすきな い19)。成熟した牛の腱のコラーゲンから得た架橋ベブチ ドにつての研究から，この架橋網目棈造に含まれる 2 つの主要なベプチドは， $\alpha_{1} \mathrm{CB}_{6}$ と $\alpha_{1} \mathrm{CB}_{5}{ }^{* 4}$ であり，その 重合したペプチドは, $1 \sim 8 の\left(\alpha_{1} \mathrm{CB}_{6}\right)_{2}-\left(\alpha_{1} \mathrm{CB}_{5}\right)$ 単位 を含んでいることを明らかにしだ19)。

MRI の所長の A. J. Bailey は, コラーダン研究の専 門家であり, 病気とコラーゲンについての研究も進めて いる。例之ば，脚の弱い㟲の関節軟骨から，タイブM といら新しいコラーゲンを分離している。このコラーゲ

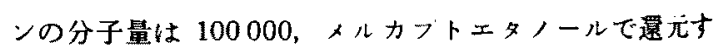
ると 30000 になる゙リ。軟骨中での分布と役割につて の研究が進行中である。

11）ストレス感受性の生化学

豚のストレス症侯 (PSE と要性高熱症) は，笳原線雉 の ATPase を活性化する $\mathrm{Ca}^{2+}$ の增加によって引き崫 こされ，正常群に比へて，速い解糖速度を産みたすと考 えられている。ストレスに弱い系統の豚 (Pietrain 系) 
と想受性のない系統の腺 (Hampshire 系) の背最長肪か ら、ミトコンドリアと笳小胞体を調製して研究を進めた。

八ロセン感受性豚"5 のミトコンドリアは，ハロセン非 㛑受性 (正常) 豚のミトコンドリアに比べて，多量の $\mathrm{Ca}^{2+}$ 含んでいた。これは前者の高い囄 $\mathrm{Ca}^{2+}$ レベル を反映したすのである。ミトコンドリア内の $\mathrm{Ca}^{2+}$ 量は， 筋肉 $\mathrm{pH}$ の死後の低下速度, 肉質及び八ロ七ン感受性と 密接な関係があっだ22)。

ハロセン感受性豚のミトコンドリアによる, $\mathrm{Ca}^{2+}$ 活性 化コハク酸の酸化の遷移温度は, 正常に比へて $9^{\circ} \mathrm{C}$ む高 かった。橎移温度の差は、ホスホリパーピの阻害用であ

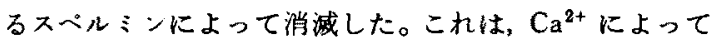
活性化されるホスホリパーゼ $\mathrm{A}_{2}$ が僄移温度の差をもた らすことを示している。八ロセン感受性豚のミトコンド リアは, 内部に長鎖の脂肪酸を非感受性啀よりも多量に 含み、ホスホりパーゼ $A_{2}$ 活性む 2 倍である。

ロセン感受性及び正常豚から分離した笳小胞体の $\mathrm{Ca}^{2+}$ 集積能力は，八ロセン感受性滕のミトコンドリフに より低下させられた。しかし，八ロセン非感受性豚のミ トコンドリアは何んの効果も示さなかった。この効果 は、ミトコンドリアの $\mathrm{Ca}^{2+}$ 活性化ホスホリハーーゼの作 用によってできた脂肪酸のためである ${ }^{23) 24 。}$

ストレス感受性を抵抗性と区別するための信頼できる スクリーニング法を確立するために，種々の生化学的テ ストが行なわれた。ミトコンドリアからの Ca ${ }^{2+}$ の流出 を测定する簡単な方法が開発されないと実用化は困難で ある。一方，血液を出発物質とするための努力が行なわ れている。洛透ショックを与えると，八ロセン感受性 豚の赤血球膜は正常腺の赤血球膜よりも脆弱となる。そ して，この赤血球の脆弱性は，ストレス感受性豚を特徽 ずける他のハラィーターと一數している。又, 両タイブ

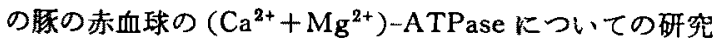

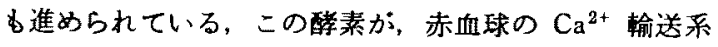
と強い関連を持っているためである゙。

以上，MRI ての研究内容の概要を、著者の理解の筙

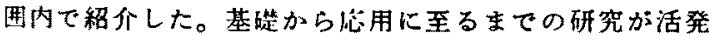
に行なわれていることに深い感銘を受けた。

\section{註}

*1 Cold shortening 動物を屠殺して死後硬直が始まる前に，急激に屠 体を低温条件下に置くと，硬い肉になること。

*2 toughening 肉声硬くなること。
*3 C 监百質

筋原線維の太い線維を㭗成する致白筫の1つ。分 子量は 13.5 万で，太い線維上に周期的に存在す る。

* $\alpha_{1} \mathrm{CB}_{6}, \quad \alpha_{1} \mathrm{CB}_{5}$

$\mathrm{CB}_{6}$ と办 $\mathrm{CB}_{5}$ の後の番号は， $\alpha_{1}$ 成分を，臭化 シフン (CNBr) で切断したぺブチドを，ク口マ トグラフィーで分蜼したときの溶出順を表わす。

*3 八口セン撼受性豚

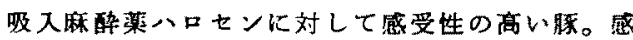
受性が高いということは，ストレスに弱いという ことになる。

\section{文献}

本稿を執筆するにあたり，MRI の Biennial Report を参照した，促って，特定の文献を記載しなかった箇所 は,この Reportを参照されたい。

1) Meat Research Institute Biennial Report, 1979 -1981, (Agricultural Research Council), (1982).

2) Lister, D., Gregory, N. G. and WarRis, P. D.: Developments in Meat Science-2 (Applied Science Publishers, London), p. 61 (1981).

3 Spencer, G. S. G., Wilkins, L. J. and Lister, D. : Experientia, 37, 152 (1981).

4) Spencer, G. S. G.: J. Sci. Food Agric., 30, 1108 (1979).

5) Gregory, N. G., Wood, J. D., ENSER, M., Sмith, W. C. and Ellis, M.: J. Sci. Food Agric., 31, 567 (1980).

6) HALl, G. M., LUCKE, J. N. and Lister, D. Br. J. Anaesth., 52, 165 (1980).

7) Hall, G. M., Lucke, J. N., Lovell, R. D. L. and Lister, D.: Br. J. Anaesth., 52, 11 (1980).

8) BaIley, C. and James, S. J.: Meat, 52, 38 (1979).

9) BAILEY, C.: Meat, 52, 39 (1979).

10) JAmes, S. J. and CReed, P. G.: Int. J. Refrig., 3, 237 (1980).

11) Taylor, A. A., Shaw, B. G. and MacDougall, D. B.: Meat Sci., 5, 109 (1981).

12) Skjelyale, R., Stringer, M. F. and Smart, J. L. : J. Appl. Bact., 41, 329 (1979).

13) Dainty, R. H. and Hibbard, C. M.: $J . A p p l$. Bact., 48, 387 (1980).

14) Wood, J. D., Mottram, D. S. and Brown, A. J.: Animal Prod., 32, 117 (1981).

15) Trinick, J. A. and Offer, G. W.: Proc. $8 t h$ European Mecting on Musclc and Motility, p. 33 (1979).

16) Trinick, J. A. and Cooper, J. A. M.: J. Mol. Biol., 141, 315 (1980).

17) Etherington, D. J.: CIBA Foundation Symp. 75 (Excerpta Medica, Amsterdam), p. 87 
(1980)

18) Etherington, D. J., Silver, I. A. and Restall, D. J. : Br. J. Exp. Path., 60, 549 (1979).

19) Sims, T. J. and Balley, A. J.: Developments in Meat Science-2 (Applied Science Pub. lishers, London), p. 29 (1981).

20) Duance, V. C., Black, C. M., Dubowitz, V., Hughes, G. V. R, and BaIley, A. J.: Muscle and Nerve, 3, 487 (1980).

21) Shimokomaki, M., Duance, V. C. and Bailey,
A. J.: FEBS Lett., 121, 51 (1980).

22) С̆еaн, K. S. and Cheah, A. M.: FEBS Lett. 107, 265 (1979)

23) С heah, K. S. and Cheah, A. M.: Proc. Ist European Conf. on Bioenergetics, Ulbino, Italy, p. 397 (1980).

24) Сheah, K. S. and Сheah, A. M.: Biochim. Biophys. Acta, 634, 70 (1981).

(昭和 59 年 2 月 2 日受理)

\section{新刊紹介}

Physical Properties of Foods

Peleg M. and Bagley E.B. 䓊

IFT-IUFoST Basic Symposium かi 1982 年 6 月, 六 タ州ラスベガスで開催され，本書はその際の諈演内容に 基ついてとりまとめられたるのである。食品加工に関す る機器装置や，熟とか電気とかの Engineering につい ては，本書では意識的に避けている。シンポジウムでの

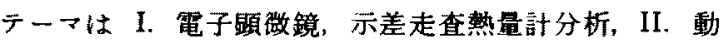
物性食品, 植物性食品, 組立食品, 焙焼食品, その他の 食品に閶する構造打よび特性, III. 食品, ドウ生地, エ マルショョンの粘弾性, IV. 炭水化物の揮発珄, 粘着性,

相変換，の4つに分類され本書に網羅されている。

1983 年版 532 ページA 5 版

AVI Publishing Company, Inc.,

Westport, Connecticut 06881, USA 